\title{
PENDIDIKAN ISLAM DALAM PERSPEKTIF AL-GHAZALI
}

\author{
H. Zulkifli Agus \\ Sekolah Tinggi Ilmu Tarbiyah Raudhatul Ulum Sakatiga \\ Email: zulkifliagus08@gmail.com
}

\begin{abstract}
Abstrak
Pendidikan merupakan komponen penting dalam kehidupan. Hal ini menjadi pembahasan para ulama tak terkecuali Imam al-Ghazali. Untuk itu, penelitian ini membahas pendidikan Islam dalam perspektif al-Ghazali. Hasil penelitian ini adalah bahwa pendidikan menurut Al Ghazali menekankan pada pendidikan agama dan akhlak. Menurutnya pengertian dan tujuan pendidikan Islam yaitu pendidikan yang berupaya dan bertujuan dalam proses pembentukan insan paripurna. Adapun dalam membuat sebuah kurikulum, Al Ghazali memiliki dua kecenderungan, yaitu kecenderungan terhadap agama dan kecenderungan pragmatis. Adapun aspek-aspek materi pendidikan Islam menurut pemikiran Al Ghazali adalah meliputi: pendidikan keimanan, akhlak, akal, sosial dan jasmani. Menurutnya guru yang baik itu selain cerdas dan sempurna akalnya, juga harus memiliki sifat-sifat yang terpuji. Adapun sifat yang harus dimiliki oleh seorang murid yaitu rendah hati, mensucikan diri dari segala keburukan taat dan istiqamah. Sementara yang menjadi evaluasi pendidikan adalah semua bentuk aktifitas yang terkait dengan tugas tanggung jawabnya masing-masing dalam proses pendidikan.
\end{abstract}

Kata Kunci: Pendidikan Islam, Akhlak, Al-Ghazali

\section{Pengertian Pendidikan Islam}

Menurut Al Ghazali, pendidikan Islam yaitu pendidikan yang berupaya dalam pembentukan insan paripurna, baik di dunia maupun di akhirat. Menurut Al Ghazali pula manusia dapat mencapai kesempurnaan apabila mau berusaha mencari ilmu dan selanjutnya mengamalkan fadhilah melalui ilmu pengetahuan yang dipelajarinya. Fadhilah ini selanjutnya dapat membawanya untuk dekat kepada Allah dan akhirnya membahagiakannya hidup di dunia dan akhirat. ${ }^{1}$

Bagi Al Ghazali, ilmu adalah medium untuk taqarrub kepada Allah, dimana tak ada satu pun manusia bisa sampai kepada-Nya tanpa ilmu. Tingkat termulia bagiseorang manusia adalah kebahagiaan yang abadi. Di antara wujud yang paling utamaadalah wujud yang menjadi perantara kebahagiaan, tetapi kebahagiaan itu tidak mungkin tercapai kecuali dengan ilmu dan amal, dan amal tak mungkin dicapai kecuali jika ilmu tentang cara beramal dikuasai. Dengan demikian, modal kebahagiaan di dunia dan akhirat itu, tak lain adalah ilmu. Maka dari itu, dapat disebut ilmu adalah amal yang terutama. ${ }^{2}$

Proses pendidikan pada intinya merupakan interaksi antara pendidik (guru) dan peserta didik (murid) untuk mencapai tujuan-tujuan pendidikan yang telah ditetapkan. Dalam konteks umum tujuan pendidikan tersebut antara lain mentrasmisikan pengalaman dari generasi ke generasi berikutnya. Pendidikan menekankan pengalaman dari seluruh masyarakat, bukan hanya pengalaman pribadi perorangan. Definisi ini sejalan dengan pendapat Jhon Dewey yang mengatakan bahwa pendidikan merupakan organisasi

\footnotetext{
${ }^{1}$ Hamdani Ihsan dan Fuad Ihsan, Filsafat Pendidikan Ilsam, (Bandung: CV Pustaka Srtia), hal 72

${ }^{2}$ Amie Primarni dan Khairunnas, Pendidikan Holistik; Format Baru Pendidikan Islam Membentuk Karakter Paripurna, (Jakarta: AMP Press, PT Al Mawardi Prima, 2016), Cet. Ke-2, hal. 113.
} 


\section{Pendidikan Islam dalam Perspektif al-Ghazali \\ H. Zulkifli Agus}

pengalaman hidup, pembentukan kembali pengalaman hidup, dan juga pembahasan pengalaman hidup sendiri. Sedangkan dalam konteks Islam pendidikan dapat diartikan sebagai proses persiapan generasi muda untuk generasi peranan, memindahkan pengetahuan dan nilai-nilai Islam yang diselaraskan dengan fungsi manusia untuk beramal di dunia danmemetik hasilnya di akhirat. ${ }^{3}$

Jadi pendidikan Islam menurut Al Ghazali merupakan pendidikan yang ingin

menjadikan manusia menjadi insan yang paripura yang nantinya akan mencapai hidup bahagia di dunia dan akhirat dengan bertaqarrub kepada Allah melalui ilmu yang sudah dia dapatkan lewat proses pendidikan.

\section{Tujuan Pendidikan Islam}

Al Ghazali menekankan tugas pendidikan adalah mengarah pada realisasi tujuan keagamaan dan akhlak, dimana fadhilah (keutamaan) dan taqarrub kepada Allah merupakan tujuan yang paling penting dalam pendidikan. ${ }^{4}$ Menurut Al Ghazali, tujuan pendidikan yaitu pembentukan insan paripurna, baik di dunia maupun di akhirat. Menurut Imam Al Ghazali pula manusia dapat mencapai kesempurnaan apabila mau berusaha mencari ilmu dan selanjutnya mengamalkan fadilah melalui ilmu pengetahuan yang dipelajarinya. Fadhilah ini selanjutnya dapat membawanya untuk dekat kepada Allah dan akhirnya membahagiakannya hidup di dunia dan di akhirat. $^{5}$

Menurut Al Ghazali tujuan utama pendidikan Islam itu adalah ber-taqarrub kepada Allah Sang Khaliq, dan manusia yang paling sempurna dalam pandangannya adalah manusia yang selalu mendekatkan diri kepada Allah. ${ }^{6}$

Untuk mencapai tujuan dari sistem pendidikan apapun, dua faktor asasi berikut ini mutlak adanya: Pertama, aspek- aspek ilmu pengetahuan yang harus dibekalkan kepada murid atau dengan makna lain ialah kurikulum pelajaran yang harus dicapai oleh murid. Kedua, metode yang telah digunakan untuk menyampaikan ilmu- ilmu atau materi-materi kurikulum kepada murid, sehingga ia benar-benar menaruh perhatiannya kepada kurikulum dan dapat menyerap faidahnya. Dengan ini, murid akan sampai kepada tujuan pendidikan dan pengajaran yang dicarinya. ${ }^{7}$

Dari hasil studi terhadap pemikiran Al Ghazali dapat diketahui dengan jelas, bahwa tujuan akhir yang ingin dicapai melalui kegiatan pendidikan ada dua: Pertama, tercapainya kesempurnaan insani yang bermuara pada pendekatan diri kepada Allah. Kedua, kesempurnaan insani yang bermuara pada kebahagiaan hidup dunia dan akhirat. Karena itu ia bercita-cita mengajarkan manusia agar mereka sampai pada sasaran-sasaran yang merupakan tujuan akhir dan maksud pendidikan itu. Tujuan itu tampak bernuansa religius dan moral, tanpa mengabaikan masalah duniawi. ${ }^{8}$

Berdasarkan uraian di atas, dapat kita ketahui bahwa Al Ghazali sangat menekankan tujuan pendidikannya pada pembentukan agama dan akhlak seseorang dimana fadhilah (keutamaan) dan taqarrub kepada Allah merupakan tujuan yang paling penting dalam pendidikan untuk menjadikan seseorang menjadi insan paripurna yang nantinya akan membuatnya hidup bahagia di dunia dan di akhirat.

\footnotetext{
${ }^{3}$ Abuddin Nata, Perspektif Tentang Pola Hubungan Guru-Murid, (Jakarta : PT Raja Grafindo Persada, 2015), Cet. Ke-2, hal. 83.

${ }^{4}$ Ali Al Jumbulati, Perbandingan Pendidikan Islam,(Jakarta: PT Renika Cipta), hal. 134.

${ }^{5}$ Hamdani Ihsan dan Fuad Ihsan, Filsafat Pendidikan ...., hal. 72

${ }^{6}$ Ramayulis, Filsafat PendidikanIslam, (Jakarta Kalam Mulia), hal. 121.

${ }^{7}$ Fathiyyah Hasan Sulaiman, Alam Pikiran Al Ghazali Mengenai Pendidikan dan Ilmu, (Bandung : CV Diponegoro, 1986), Cet. Ke-1, hal. 28.

${ }^{8}$ Abuddin Nata, Pemikiran Para Tokoh Pendidikan Islam, (Jakata : PT Raja Grafindo Persada, 2000), Cet. Ke-1, hal. 86 .
} 


\section{Metode dan Kurikulum Pendidikan Islam}

\section{Metode Pendidikan Islam}

Dalam rangka mewujudkan konsep pendidikannya, Al Ghazali menggunakan metode pengajaran yang menggunakan keteladanan, pembinaan budi pekerti, dan penanaman sifatsifat keutamaan pada diri muridnya. Hal ini sejalan dengan prinsipnya yang mengatakan bahwa pendidikan adalah sebagai kerja yang memerlukan hubungan erat antara dua pribadi, yaitu guru dan murid. ${ }^{9}$

Pendidikan agama dan akhlak merupakan sasaran Al Ghazali yang paling penting. Dia memberikan metode yang benar untuk pendidikan agama, pembentukan akhlak dan pensucian jiwa. Dia berharap dapat membentuk individu-individu yang mulia dan bertaqwa, selanjutnya dapat menyebarkan keutamaan-keutamaan kepada seluruh umat manusia. ${ }^{10}$

Dalam uraiannya yang lain, Al Ghazali menjelaskan bahwa metode pendidikan yang harus dipergunakan oleh para pendidik/pengajar adalah yang berprinsip pada child centeredatau yang lebih mementingkan anak didik daripada pendidik sendiri.Metode demikian dapat diwujudkan dalam berbagai macam metode antara lain:

1) Metode contoh teladan

2) Metode guidance and counselling (bimbingan dan penyuluhan)

3) Mtode cerita

4) Metode motivasi

5) Metode reinforcement (mendorong semangat) ${ }^{11}$

Jadi berdasarkan uraian di atas, dapat ditarik kesimpulan bahwa metode pendidikan menurut $\mathrm{Al}$ Ghazali diklasifikasikan menjadi dua bagian:

1. Metode Pendidikan Agama, yaitu dengan menggunakan metode hafalan dan pemahaman, kemudian dilanjutkan dengan keyakinan dan pembenaran, setelah itu penegakan dalil-dalil yang menunjang penguatan akidah. .

2. Metode Pendidikan Akhlak, yaitu dengan menggunakan keteladan, latihan dan pembiasaan

\section{Kurikulum Pendidikan Islam}

Dalam menyusun kurikulum pelajaran, Al Ghazali memberi perhatian khusus pada ilmu-ilmu agama yang sangat menentukan bagi kehidupan masyarakat. Al Ghazali agaknya menginginkan bahwa umat Islam memiliki gambaran yang makro, dan utuh tentang agama, yang diyakininya sebagai sumber ilmu pengetahuan dan landasan yang dipahami dengan sungguh-sungguh yang pada kenyataannya kemudian menjadi cara berpikir yang penting dalam memberikan kerangka bangunan ilmu pengetahuan. ${ }^{12}$

Beliau telah membagi ilmu pengetahuan yang terlarang dipelajari atau wajib dipelajari oleh anak didik menjadi tiga kelompok ilmu, yaitu:

a. Ilmu yang tercela, banyak atau sedikit. Ilmu ini tak ada manfaatnya bagi manusiadi dunia ataupun di akhirat, misalnya ilmu sihir, nujum, dan ilmu perdukunan. Bila ilmu ini dipelajari akan membawa mudarat dan akan meragukan kebenaran adanya Allah.

\footnotetext{
${ }^{9}$ Amie Primarni dan Khairunnas, Pendidikan Holistik Formata Baru Pendidikan Islam Membentuk Karakter paripurna,( Jakarta AMP Press, PT Al Mawardi Prima),hal. 129.

${ }^{10}$ Fathiyyah Hasan Sulaiman, Alam Pikiran Al Ghazali Mengenai Pendidikan dan Ilmu ,(Bandung: CV Diponogoro), hal. 28.

${ }_{11}$ Muzayyin Arifin, Filsafat PendidikanIslam, (Jakarta: PT Bumi Aksara), hal. 95.

12 Amie Primarni dan Khairunnas, Pendidikan Holistik ...., hal. 113.
} 


\section{Pendidikan Islam dalam Perspektif al-Ghazali}

\section{H. Zulkifli Agus}

b. Ilmu yang terpuji, banyak atau sedikit, misalnya ilmu tauhid, ilmu agama. Ilmu ini jika dipelajari akan membawa orang kepada jiwa yang bersih dari kerendahan dan keburukan serta dapat mendekatkan diri kepada Allah.

c. Ilmu yang terpuji pada taraf tertentu, ang tidak boleh didalami, karena ilmu ini dapat membawa kepada kegoncangan iman dan ilhad, misalnya ilmu filsafat. ${ }^{13}$

Dari ketiga kelompok ilmu tersebut, Al Ghazali membagi lagi menjadi dua kelompok dilihat dari kepentingannya, yaitu:

1) Ilmu-ilmu yang fardhu 'ainyang wajib dipelajari oleh semua orang Islam meliputi ilmuilmu agama yakni ilmu yang bersumber dari kitab suci al-Qur'an dan hadits.

2) Ilmu yang merupakan fardhu kifayah untuk dipelajari setiap muslim. Ilmu ini adalah ilmu yang dimanfaatkan untuk memudahkan urusan hidup duniawi, misalnya ilmu hitung (matematika), ilmu kedokteran, ilmu teknik, ilmu pertanian dan industri. ${ }^{14}$

Al Ghazali mengusulkan beberapa ilmu pengetahuan yang harus dipelajari di sekolah sebagai berikut:

a) Ilmu al-Qur'an dan ilmu agama, seperti fikih, hadits dan tafsir.

b) Sekumpulan bahasa, nahwu dan makhraj serta lafaz-lafaznya, karena ilmu ini berfungsi membantu agama.

c) Ilmu-ilmu yang fardhu kifayah, yaitu ilmu kedokteran, matematika, dan teknologiyang beraneka macam jenisnya, termasuk juga ilmu politik.

d) Ilmu kebudayaan seperti syair, sejarah dan beberapa cabang filsafat. ${ }^{15}$

Dalam membuatsebuah kurikulum pendidikan, Al Ghazali memiliki dua kecenderungan sebagai berikut:

Pertama, kecenderungan terhadap agama dan tasawuf. Kecenderungan ini membuat

Al Ghazali menempatkan ilmu-ilmu agama di atas segalanya dan memandangnya sebagai alat untuk menyucikan dan membersihkan diri dari pengaruh kehidupan dunia. Kecenderungan ini membuat $\mathrm{Al}$ Ghazali lebih mementingkan pendidikan etika, karena menurutnya ilmu ini berkaitan erat dengan ilmu agama.

Kedua, kecenderungan pragmatis. Kecenderungan ini tampak dalam karya tulis Al Ghazali. Dia menjelaskan bahwa ilmu yang tidak bermanfaat bagi manusia merupakan ilmu yang tak bernilai. Bagi Al Ghazali, setiap ilmu harus dilihat dari fungsi dan kegunaannya dalam bentuk amaliyah. Dan setiap amaliah yang disertai ilmu harus pula disertai dengan kesungguhan dan niat yang tulus ikhlas. ${ }^{16}$

Jadi berdasarkan uraian di atas, dapat kita simpulkan bahwa dalam penyusunan kurikulum pendidikan, Al Ghazali memberikan perhatian khusus pada ilmu-ilmu agama, karena dengan bermodalkan ilmu-ilmu agama tersebut, seseorang dapat beramal dengannya dan meraih kebahagiaan di dunia dan akhirat.

\section{Aspek-Aspek Pendidikan Islam \\ Pendidikan Keimanan}

Iman Menurut al-Ghazali

Menurut Al Ghazali "Iman adalah mengucapkan dengan lidah, mengakui benarnya dengan hati danmengamalkan dengan anggota." ${ }^{17}$ Dari definisi ini kita bisa pahami bahwa pendidikan keimanan meliputi tiga prinsip; Ucapan lidah atau mulut, karena lidah adalah penerjemah dari hati. Pembenaran hati, dengan cara itikad dan taklid bagi orang awam atau manusia pada umumnya, dan secara kasyaf (membuka hijab hati) bagi orang khawas. Amal

\footnotetext{
${ }^{13}$ Muzayyin Arifin, Filsafat Pendidikan ...., hal. 80.

${ }^{14}$ Hamdani Ihsan dan Fuad Ihsan, Filsafat Pendidikan ...., hal. 142.

${ }^{15}$ Ramayulis, Filsafat Pendidikan ...., hal. 319.

${ }^{16}$ Abuddin Nata, Pemikiran Para ....., hal. 93.

${ }^{17}$ Hamdani Ihsan dan Fuad Ihsan, Filsafat Pendidikan ...., hal. 235.
} 
Volume 3 Nomor 2 Edisi Desember 2018

P-ISSN : 2541-3686

perbuatan yang dihitung dari sebagian iman, maka bertambah dan berkurangnya iman seseorang bergantung pada amal perbuatan. ${ }^{18}$

Al Ghazali di dalam bukunya Akidah al-Muslim menjelaskan hubungan antara iman dan Islam ini mengatakan bahwa iman dan Islam menurut syara' mempunyai pengertian yang sama dan saling melazimi. Hakikat Islam adalah melaksanakan segala ibadah yang wajib atau sunnah, yakni pembenaran terhadap adanya Tuhan dan menjalankan segala perintah-Nya; dan hakikatiman ialah ma'rifah yang benar dan menjalankan segala yang berhubungan dengannya. Oleh karena itu, makna yakin terkandung di dalam Islam dan makna tunduk (patuh) terkandung di alam iman. Maka tidaklah dapat pula diterima Islam tanpa yakin sebagaimana tidak dapat diterima iman tanpa tunduk kepada Allah. ${ }^{19}$

\section{Pendidikan Keimanan Bagi Anak-anak (Anak Didik)}

Al Ghazali menganjurkan tentang asas pendidikan keimanan ini agar diberikan kepada anak-anak sejak dini supaya dia bisa menghafal, memahami, beriktiqat, mempercayai, kemudian membenarkan sehingga keimanan pada anak hadir secara sedikit demi sedikit hingga sempurna, kokoh dan menjadi fundamen dalam berbagai aspek kehidupannya dan bisa mempengaruhi segala perilakunya mulai dari pola pikir, pola sikap, pola bertindak, dan pandangan hidupnya. ${ }^{20}$

Al Ghazali mengatakan: "Apabila akidah telah tumbuh pada jiwa seorang mukmin, maka tertanamlah dalam jiwanya rasa bahwa hanya Allah sajalah yang paling berkuasa, segala maujud yang ada ini hanya makhluk belaka., ${ }^{21}$

Al Ghazali menganjurkan agar dalam mendidik dan meningkatkan keimanan anak menggunakan cara yang halus dan lemah lembut, bukan dengan paksaan ataupun dengan berdebat, sehingga dengan mudah dan senang akan diterima anak.

\section{Pendidikan Akhlak}

\section{Akhlak Menurut Al Ghazali}

Menurut Imam Al Ghazali, akhlak merupakan tabiat manusia yang dapat dilihat dalam dua bentuk, yaitu: Pertama, tabiat-tabiat fitrah, kekuatan tabiat pada asal kesatuan tubuh dan memiliki kelanjutan selama hidup. Sebagian tabiat itu lebih kuat dan lebih lama dibandingkan dengan tabiat lainnya. Seperti tabiat syahwat yang ada pada diri manusia. Kedua, akhlak yang muncul dari suatu perangai yang banyak diamalkan dan ditaati, menjadi bagian dari adat kebiasaan yang berurat berakar pada dirinya. Akhlak menurut pengertian Islam adalah salah satu hasil dari iman dan ibadat. Hal ini disebabkan, karena iman dan ibadat manusia tidak sempurna kecuali kalau dari situ muncul akhlak yang mulia. ${ }^{22}$

Al Ghazali menerangkan bahwa berakhlak baik atau berakhlak terpuji ituartinya menghilangkan semua adat-adat kebiasaan yang tercela yang sudah dirincikan oleh agama Islam serta menjauhkan diri dari padanya, sebagimana menjauhkan diri dari najis dan kotoran, kemudian membiasakan adat kebiasaan yang baik, menggemarinya, melakukannya dan membiasakannya. ${ }^{23}$

\section{Pendidikan Akhlak Bagi Anak Didik}

Sebelum anak dapat berpikir logis dan memahami hal -hal yang abstrak, serta belum sanggup menentukan mana yang baik dan mana yang buruk (tamyiz), mana yang benar dan

\footnotetext{
${ }^{18}$ Ibid., hal. 236.

${ }^{19}$ Asmaran As, Pengantar Studi Akhlak, (Jakarta : PT Raja Grafindo Persada, 2002), Cet. Ke-3, hal. 105.

${ }^{20}$ Hamdani Ihsan dan Fuad Ihsan, Filsafat Pendidikan ...., hal. 237.

${ }^{21}$ Asmaran As, Pengantar Studi ...., hal. 97.

${ }^{22}$ Ramayulis, Filsafat Pendidikan ...., hal. 261.

${ }^{23}$ Asmaran As, Pengantar Studi Akhlak, ( Jakarta: Raja Grapindo Persada),hal. 206.
} 


\section{Pendidikan Islam dalam Perspektif al-Ghazali}

\section{H. Zulkifli Agus}

mana yang salah, maka contoh-contoh, latihan-latihan dan pembiasaan- pembiasaan (habit forming) mempunyai peranan yang sangat penting, dalam pembinaan pribadi anak, karena masa kanak-kanak adalah masa paling baik untuk menanamkan dasar-dasar pendidikan akhlak. $^{24}$

Menurut Al Ghazali, kepribadian manusia itu pada dasarnya dapat menerimasegala usaha pembentukan. Jika manusia membiasakan perbuatan jahat, maka dia akan menjadi orang yang jahat. Oleh karena itu,akhlak harus diajarkan, yaitu dengan melatih jiwa kepada pekerjaan atau tingkah laku yang mulia. Jika sesorang menghendaki agar dia menjadi pemurah, ia harus membiasakan dirinya melakukan pekerjaan-pekerjaan yang bersifat pemurah, hingga murah hati dan murah tangan itu menjadi tabi'at baginya. ${ }^{25}$

Akhlak yang baik tidak akan dapat terbentuk kecuali dengan membiasakanseseorang untuk berbuat sesuatu pekerjaan yang sesuai dengan sifat akhlak itu. Jikaseseorang mengulang-ulangi berbuat sesuatu yang tertentu maka berkesanlah pengaruhnya terhadap perilakunya dan menjadi kebiasaan moral dan wataknya. ${ }^{26}$

Baiknya akhlak atau budi pekerti itu kembali kepada lurusnya kekuatan akal , sempurnanya hikmah dan lurusnya hawa nafsu. Semuanya itu sesuai dengan akal dan syara'. Semuanya itu dikarenakan dua hal: Pertama, dengan karunia Allah sempurnanya fitrah, dimana manusia itu diciptakan dan dilahirkan dengan sempurnanya akal dan baiknya budi pekerti. Dan bahwa watak dan fitrah manusia itu terdapat sesuatu yang kadang-kadang tercapai dengan usaha. Kedua, dengan mengusahakan budi pekerti itu dengan mujahadah dan latihan.Yaitu mendorong jiwa dan hati untuk menerjakan perbuatan-perbuatan yang dikehendaki oleh budi pekerti yang dicari. ${ }^{27}$

Menurut Al Ghazali baik atau buruknya akhlak seseorang dapat berpengaruh pada jiwa seseorang. Menurutnya pengobatan pada jiwa manusia adalah dengan menghilangkan segala perilaku dan akhlak yang buruk. Dan melakukan segala kebaikan dan akhlak yang terpuji. Seperti tubuh yang pengobatannya adalah dengan menghilangkan segala penyakit dari tubuh, serta mengusahakan menjaga kesehatannya. ${ }^{28}$

Maka dari pendapat beliau dapat disimpulkan bahwa baik buruknya akhlak seseorang dapat berpengaruh pada kesehatan jiwanya. Jika seseorang ingin jiwanya baik dan sehat, maka dia harus menghiasi dirinya dengan akhlak dan budi pekerti yang baik. Begitu juga sebaliknya, orang yang terbiasa dengan budi pekerti dan akhlak yang buruk, maka ia akan memiliki jiwa yang buruk dan tidak sehat pula. Dan budi pekerti dan akhlak yang baik itu dapat diusahakan dengan jalan latihan dan pembiasaan.

\section{Pendidikan Akliah}

\section{Akal Menurut Al Ghazali}

"Akal adalah sebagai sumber ilmu pengetahuan tempat terbit dan sendi-sendinya. Ilmu pengetahuan itu berlaku dari akal, sebagaimana berlakunya buah-buahandari pohon, sinar dari matahari dan penglihatan dari mata." ${ }^{29}$ Dalam kitab Ihya' Ulumiddin, dijelaskan hakikat akal yang meliputi: Yang pertama adalah akal merupakan sifat yang membedakan antara manusia dengan seluruh binatang. Yang kedua adalah ilmu- ilmu yang keluar dari dalam diri anak kecil yangmumayyiz(sudah dapat membedakan) terhadap mana yang boleh dan mana yang tidak boleh dilakukan. Yang ketiga adalah ilmu-ilmu yang diperoleh dengan

\footnotetext{
${ }^{24}$ Hamdani Ihsan dan Fuad Ihsan, Filsafat Pendidikan ...., hal. 240.

${ }^{25}$ Asmaran As, Pengantar Studi Akhlak..., hal. 47.

${ }^{26}$ Ali Al Jumbulati, Perbandingan Pendidikan ...., hal. 158.

${ }^{27}$ Al Ghazali, Terjemah Ihya' Ulumiddin, (Semarang : CV Asy Syifa', 2009), Jilid 5, Cet. Ke-30, hal.

${ }^{28}$ Ibid., hal. 132.

${ }^{29}$ Hamdani Ihsan dan Fuad Ihsan, Filsafat Pendidikan ...., hal. 251.
} 123. 
Volume 3 Nomor 2 Edisi Desember 2018

P-ISSN : 2541-3686

pengalaman dengan berjalannya keadaan-keadaan. Orang yang didik oleh pengalamanpengalaman dan aliran-aliran maka biasanya ia disebut sebagai orang yang berakal.

Kekuatan naluri itu berakhir hingga seseorang mengetahui kesudahan berbagai perkara dan mampu menahan syahwat (keinginan). Apabila kekuatan ini berhasil maka pemiliknya disebut sebagai orang yang berakal. ${ }^{30}$

Hakikat akal adalah naluri yang dengannya manusia siap untuk memahami pengetahuan-pengetahuan teoritis. Seolah-olah akal merupakan cahaya yang dimasukkan ke dalam hati dan dipersiapkan untuk memahami benda-benda, dan ia bertingkat-tingkat sesuai dengan tingkatan naluri. ${ }^{31}$

Fungsi akal manusia terbagi kepada enam, yaitu: Akal adalah penahan nafsu. Dengan akal manusia dapat mengerti apa yang tidak dikehendaki oleh amanat yang dibebankan kepadanya sebagai sebuah kewajban. Akal adalah pengertian dan pemikiran yang berubah-ubah dalam menghadapi sesuatu baik yang tampak jelas maupun yang tidak jelas. Akal adalah petunjuk yang dapat membedakan hidayah dan kesesatan. Akal adalah kesadaran batin dan pengaturan tingkah laku. Akal adalah pandangan batin yang berdaya tembus melebihi penglihatan mata. Akal adalah daya ingat mengambil dari yang telah lampau untuk masa yang sedang dihadapi. $^{32}$

\section{Pendidikan Akliah Bagi Anak-anak (Anak didik)}

Pendidikan akal bertujuan untuk memperbesar perbuatan tenaga akal dan membentuk kecakapan akal menjalankan tugasnya. Cakap berarti dalam waktu singkat dapat menjelaskan tugas dengan jitu. Dalam kata jitu itu terkandung pengertian benar, tepat dan sempurna. Oleh karena tugas akal itu adalah mengenali dan menyelami seluk beluk sesuatu dalam rangka memecahkan suatu problem, maka tujuan pendidikan akal itu adalah memperbesar kekuatan tenaga akal dan membentuk kecakapan akal mengenai dan menyelami seluk beluk sesuatu problem yang bertalian dengan Tuhan, manusia atau masyarakat dan alam, sehingga dapat mencapai keyakinan yang pasti. Titik ujung dari kerja akal adalah terlahirnya suatu keyakinan yang pasti (haqul yakin), suatu keyakinan yang di dalamnya tidak lagi terselip unsur-unsur ragu-ragu dan unsur sesat (salah) atau keliru. ${ }^{33}$

Bahan-bahan yang dapat diajarkan dalam kitab-kitab untuk mendidik akal terdiri dari: Al Qur'anulkarim. Hadis-hadis tentang cerita atau hikayat-hikayat orang-orang baik (saleh) agar anak mencintai orang saleh sejak waktu kecilnya. Memberikan hafalan syair-syair yang menyentuh pada perasaaan rindu dan antusias anak terhadap nilai pendidikan. Dan janganlah mendekatkan anak kepada ajakan pada pendidik yang menganjurkan menghafal syair-syair yang membawa kepada situasi yang melemahkan perasaan. ${ }^{34}$

Aspek pendidikan akliah dapat dilaksanakan dengan cara:

a. Mempelajari berbagai macam ilmu pengetahuan sedalam-dalamnya dan menguasainya secara intens dan akurat.

b. Mengadakan pengamatan, penelitian dan tafakur terhadap alam semesta dengan berbagai macam kegiatan, baik oleh anak maupun orang dewasa.

c. Mengamalkan semua ilmu pengetahuan yang telah diperolehnya untuk meningkatkan kesejahteraan umat manusia dan untuk pengabdian (kepentingan peribadatan) pada Khaliqul Alam. ${ }^{35}$

\footnotetext{
${ }^{30}$ Al Ghazali, Terjemah Ihya' Ulumiddin, (Semarang : CV Asy Syifa, 2003), Jilid 1, hal. 271.

${ }^{31}$ Abu Madyan Al Qurtubi, Mukhtashar Ihya' Ulumiddin, (Depok : Keira Publishing, 2014), Cet. Ke-1, hal. 23.

${ }^{32}$ Ramayulis, Fisafat Pendidikan ...., hal. 257.

${ }^{33}$ Akmal Hawi, Dasar-Dasar Pendidikan Islam, (Palembang : IAIN Raden Fatah Press) hal. 147.

${ }^{34}$ Ali Al Jumbulati, Perbandingan Pendidikan ...., hal. 150.

${ }^{35}$ Hamdani Ihsan dan Fuad Ihsan, Filsafat Pendidikan ...., hal. 254.
} 


\section{Pendidikan Islam dalam Perspektif al-Ghazali}

\section{H. Zulkifli Agus}

Demikian tinggi fungsi berpikir yang digambarkan oleh Al Ghazali, sehingga akal pikiran tidak akan menjadi cerdas dan berguna, selama akal pikiran manusia tidak diperkenalkan, dipergunakan dan bahkan ditantang dengan berbagai macam ilmu pengetahuan.

\section{Pendidikan Sosial}

Konsep Sosial Menurut Al Ghazali.

Seorang manusia adalah makhluk individual dan secara bersamaan adalah makhluk sosial. Keserasian antar individu dan masyarakat tidak mempunyai kontradiksi antara tujuan sosial dan tujuan individu. Dalam Islam tanggung jawab tidak terbatas pada perorangan, tapi juga sosial sekaligus. Tanggung jawab perorangan pada pribadi merupakan asas, tapi pada saat bersamaan ia tidak mengabaikan tanggung jawab sosial yang merupakan dasar pembentuk masyarakat. ${ }^{36}$

Sesungguhnya berkasih sayang di jalan Allah SWT dan persaudaraan di jalan agamaNya adalah merupakan jalanuntuktaqarrub yang paling utama kepada-Nya dan sekaligus merupakan jalan yang paling halus yang bisa diambil faidah dari segala ketaatan pada segala adat kebiasaan yang berlaku. Yang mana kesemuanya itu tentunya memiliki syarat, dimana dengan syarat-syarat tersebut saling berhubunganlah orang-orang yang menginginkan persahabatan dengan orang-orang yang mencintai Allah SWT. Dan pada syarat-syarat itu terdapat pula hak-hak dimana dengan menjaga hak- hak itu maka bersihlah persaudaraan dari noda- noda dan dari godaan syaitan. ${ }^{37}$

Sebagaimana dalam hadits Rasulullah SAW:
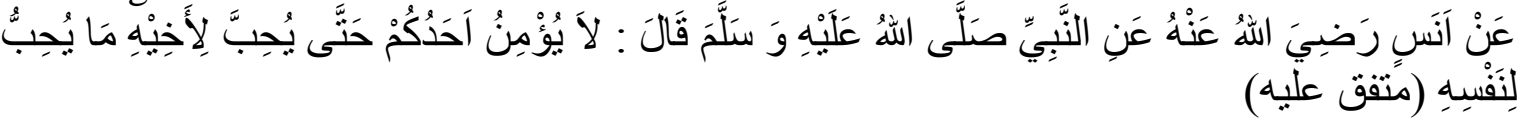

Artinya :

Dari Anas ra meriwayatkan dari Nabi SAW yang bersabda, "Tidak sempurna iman seseorang hingga ia mencintai saudaranya seperti mencintai dirinya sendiri.." (Muttafaqun 'alaihi). ${ }^{38}$

\section{Pendidikan Sosial Bagi Anak Didik}

Al Ghazali memberikan petunjuk kepada orang tua dan para pendidik umumnya agar anak-anak dalam pergaulan dan kehidupannya mempunyai sifat-sifat yang mulia dan memiliki etika pergaulan yang baik, sehingga ia dapat menyesuaikan dirinya dengan lingkungannya dan dapat membatasi pergaulannya. Sifat-sifat itu adalah:

- Menghormati dan patuh kepada kedua orang tua dan orang dewasa lainnya.

- Merendahkan diri dan lemah lembut.

- Membentuk sikap dermawan.

- Membatasi pergaulan anak. ${ }^{39}$

Adapun usaha -usaha yang dapat dilakukan untuk mengisi pergaulan social dengan akhlak Islami berupa:

1) Tidak melakukan hal-hal yang keji dan tercela seperti, membunuh, menipu, riba, merampok, makan harta anak yatim, menyakiti anggota masyarakat dan sebagainya.

\footnotetext{
${ }^{36}$ Ramayulis, Filsafat Pendidikan ...., hal. 267.

${ }^{37} \mathrm{Al}$ Ghazali, Terjemah Ihya Ulumiddin III, (Semarang : CV Asy Syifa, 2003), hal. 501.

${ }^{38}$ An Nawawi, Riyadhus Shalihin dan Penjelasannya, (Jakarta : Ummul Qura, 2014), Cet. Ke-1, hal.

${ }^{39}$ Hamdani Ihsan dan Fuad Ihsan, Filsafat Pendidikan ...., hal. 257.
} 207. 
Volume 3 Nomor 2 Edisi Desember 2018

P-ISSN : 2541-3686

2) Membina hubungan tata tertib, meliputi bersikap sopan santun dalam pergaulan, meminta izin ketika masuk ke rumah orang, berkata baik dan member serta membalas salam.

3) Mempererat hubungan kerja sama dengan cara meninggalkan perbuatan-perbuatan yang dapat merusak dasar kerja sama untuk membela kejahatan, berkhianat, mengadakan saksi palsu, menyembunyikan kebenaran menganggap rendah orang lain, tidak memperdulikan keadaan masyarakat dan sebagainya.

4) Mengalakkan perbuatan-perbuatan terpuji yang memberi dampak positif kepada masyarakat antara lain berupa menepati janji, memaafkan, memperbaiki hubungan antar sesama muslim, amanah, membina kasih sayang, berbuat ikhsan terutama kepada fakir miskin, mengembangkan harta anak yatim, mengajak berbuat baik, bersifat pemurah, menyebarkan ilmu pengetahuan, membina persaudaraan dan sebagainya. ${ }^{40}$

Dari pendapat Al Ghazali di atas dapat kita simpulkan bahwa dalam menjalani kehidupannya, seseorang tidak dapat hidup sendiri. Seseorang butuh orang lain dalam menjalani kehidupannya. Maka dari itu sudah sepantasnya jika ia dalam menjalani kehidupan, setiap orang harus saling menyayangi dan saling tolong menolong.

\section{Pendidikan Jasmaniah}

\section{Konsep Jasmani Menurut Al Ghazali}

Al Ghazali menempatkan aspek jasmaniah manusia pada tingkat ketiga dari tingkattingkat kebahagiaan manusia, ia berpendapat:

"Keutamaan-keutamaan jasmaniah terdiri dari empat macam: kesehatan jasmani, kekuatan jasmani, keindahan jasmani dan panjang umur." 41

Jasmani (jism) adalah substansi manusia yang terdiri atas struktur organism fisik. Organisme fisik manusia lebih sempurna dibandingkan dengan organisme fisik makhluk lain. Setiap makhluk biotik-lahiriah memiliki unsur material yang sama, yakni terbuat dari unsur tanah, api, udara dan air. Keempat unsur di atas merupakan materi yang abiotik (mati), ia akan hidup jika diberi energi kehidupan yang bersifat fisik (thaqah al-jismiyah). Energi kehidupan ini lazimnya disebut dengan nyawa, karena nyawa manusia hidup. Al Ghazali menyebutkan energi tersebut dengan ar-ruh jasmaniah (ruh material). Dengan daya ini jasad manusia bernafas, merasakan sakit, panas, dingin, pahit manis, haus lapar, seks dan sebagainya. $^{42}$

Aspek jasmaniah merupakan salah satu dasar pokok untuk mendapatkan kemajuan dan kebahagiaan dalam kehidupan manusia. Akal dan jiwa yang sehat terdapat pada jasmani yang sehat pula. Hubungan antara jasmaniah dan rohaniah manusia saling memberikan pengaruh timbal balik, yaitu hal-hal yang berpengaruh pada jiwa akan akan berpengaruh pada jasmani, demikian sebaliknya. ${ }^{43}$

\section{Pendidikan Jasmaniah Bagi Anak didik}

Al Ghazali secara khusus memperhatikan pendidikan jasmani, karena dapat memperkuat jasmani, serta menumbuhkan kecakatan dan kegairahan hidup. Beliau menyatakan: "Hendaknya anak dibiasakan dengan berjalan-jalan, gerakan-gerakan dan latihan jasmani di waktu siang hari, agar supaya tidak menjadi pemalas."44

Adapun pendidikan jasmaniah bagi anak-anak maupun orang dewasa, yaitu:

\footnotetext{
${ }^{40}$ Ramayulis, Filsafat Pendidikan ...., hal. 203.

${ }^{41}$ Ibid., hal. 259.

${ }^{42}$ Ramayulis, Filsafat Pendidikan ...., hal. 287.

${ }^{43}$ Hamdani Ihsan dan Fuad Ihsan, Filsafat Pendidikan ...., hal. 259.

${ }^{44}$ Ali Al Jumbulati, Perbandingan Pendidikan ...., hal. 151.
} 


\section{Pendidikan Islam dalam Perspektif al-Ghazali}

\section{H. Zulkifli Agus}

Kesehatan dan kebersihan.Menurut $\mathrm{Al}$ Ghazali bersuci itu ada empat tingkatan, yaitu:

1) Mensucikan badan dari hadats, kotoran dan lebihan.

2) Mensucikan anggota badan dati tindak kejahatan dan dosa-dosa.

3) Mensucikan hati dari akhlak yang tercela dan kehinaan-kehinaan yang dibenci.

4) Mensucikan sir (rahasia) dari sesuatu selain Allah Ta'ala, yaitu kesucian para Nabi dan para shiddiqin. $^{45}$

Membiasakan makan suatu makanan yang baik, sekedar mencukupi kebutuhan badan dan menguatkan.

Makanan dan minuman adalah sarana untuk memperkuat dan menyegarkan jasmaniah agar dengan kekuatan tubuhnya, seseorang mampu melaksanakan perbuatan yang baik dan terpuji, untuk beribadah kepada Allah SWT. Pada hakikatnya kesehatan jasmani tidak akan mendatangkan bebagai penyakit yang diakibatkannya. Al Ghazali mengajurkan agar membiasakan makan dan minum dari bahan yang halal dan caramemperolehnya pun halal, sebaiknya agar menghindari barang yang haram ataupun syubhat (tidak jelas didapat). ${ }^{46}$

Bermain dan berolahraga

Menurut Al Ghazali anak diizinkan untuk bebas bermain setelah pulang sekolah, dan untuk beristirahat setelah belajar di sekolah, tapi jangan sampai lelah lantaran bermain, karena melarang anak bermain, dan mengekang terus belajar akan mematikan hati dan menghilangkan kecerdasan serta mempersulit kehidupannya. ${ }^{47}$

Dari uraian-uraian di atas dapat kita simpulkan bahwa pendidikan pada seseorang haruslah mencakup segala aspek yang ada pada dirinya. Baik dari aspek keimanan, akhlak, akal, social dan jasmani. Dimana dalam pendidikan pada setiap aspek tersebut memiliki metode atau caranya masing-masing. Dimana metode yang

digunakan dalam mendidik setiap aspek tersebut adalah metode pendidikan Islam.

\section{Pendidik dan Peserta Didik \\ Pendidik}

Menurut Al Ghazali pendidik merupakan maslikhul kabir. Bahkan dapat dikatakan pula, pendidik mempunyai jasa lebih dibandingkan kedua orang tuanya. Itu lantaran kedua orang tuanya menyelamatkan anaknya dari sengatan api dunia, sedangkan para pendidik menyelamatkannya dari sengatan api neraka. ${ }^{48}$

$\mathrm{Al}$ Ghazali seorang pendidik Islam memandang bahwa seorang pendidik

mempunyai kedudukan utama dan sangat penting. Beliau mengemukakan tentang mulianya pekerjaan mengajar dengan perkataannya:

"Seorang alim yang mau mengamalkan apa yang telah diketahuinya, dinamakan seorang besar di semua kerajaan langit. Dia seperti matahari yang menerangi alam-alam yang lain, dia mempunyai cahaya dalam dirinya, dan dia seperti minyak wangi yang mewangikan orang lain, karena ia memang wangi. Barang siapa yang memiliki pekerjaan mengajar, ia telah memiliki pekerjaan yang besar dan penting. Maka dari itu, hendaklah ia mengajar tingkah lakunya dan kewajiban-kewajibannya. ${ }^{49}$

Dari kata-kata beliau di atas dapat kita lihat seberapa tingginya penghargaan beliau terhadap seorang guru. Hingga beliau mengumpamakan seorang guru itu seperti matahari yang menerangi dunia dan seperti minyak wangi yang memberikan keharuman bagi orang lain.

\footnotetext{
${ }^{45}$ Al Ghazali, Terjemah Ihya' Ulumiddin, (Semarang : CV. Asy Syifa, 2003), Jilid 1, hal. 177.

${ }^{46}$ Hamdani Ihsan dan Fuad Ihsan, Filsafat Pendidikan ...., hal. 261.

47 Ali Al Jumbulati, Perbandingan Pendidikan ...., hal. 151.

${ }^{48}$ Ramayulis, Filsafat Pendidikan ...., hal. 223.

${ }^{49}$ Hamdani Ihsan dan Fuad Ihsan, Filsafat Pendidikan ...., hal. 96.
} 
Volume 3 Nomor 2 Edisi Desember 2018

P-ISSN : 2541-3686

Al Ghazali mengibaratkan guru sebagai seorang penjaga dan pengaman ilmu. Diantara kewajibannya ialah tidak kikir dengan ilmunya kepada muridnya dan tidak pula berlebihan memberikannya, baik murid itu pandai ataupun bodoh. ${ }^{50}$

Menurut Al Ghazali, seperti yang dikutip oleh Fathiyah Hasan Suleiman, terdapat beberapa sifat penting yang harus dimiliki oleh guru sebagai orang yang diteladani, yaitu:

- Amanah dan tekun bekerja.

- $\quad$ Bersifat lemah lembut dan kasih sayang terhadap murid.

- Dapat memahami dan berlapang dada dalam ilmu serta orang-orang yang mengajarkannya.

- Tidak rakus pada materi.

- Berpengetahuan luas.

- Istiqamah dan memegang teguh prinsip. ${ }^{51}$

Al Ghazali menguraikan sejumlah tugas yang harus dilaksanakan oleh seorang pendidik yang dijelaskannya sebagai berikut:

1) Hendaknya seorang guru mencintai muridnya bagaikan mencintai anaknya sendiri. Pengarahan akan kasih sayang kepada murid mengandung makna dan tujuan memperbaiki hubungan pergaulan dengan anak didiknya, dan mendorong mereka untuk selalu mencintai pelajaran, guru, dan sekolah dengan tanpa berlaku kasar terhadap mereka. Dengan dasar inilah maka hubungan pergaulan antara seorang guru dan muridnya akan menjadi baik dan intim yang didasari atas rasa kasih sayang dan cinta serta kehalusan budi. ${ }^{52}$

2) Guru tidak usah mengharapkan adanya gaji dari tugas pekerjaannya, karena mendidik/mengajar merupakan tugas pekerjaan mengikuti jejak Nabi Muhammad SAW. Nilainya lebih tinggi dari ukuran harta atau uang. Mendidik adalah usaha untuk menunjukkan manusia ke arah yang hak dan kebaikan serta ilmu. Upahnyaterletak pada diri anak didik yang setelah dewasa menjadi orang yang mengamalkan apa yang ia didikan atau ajarkan. ${ }^{53}$

3) Guru hendaknya menasehati siswanya agar tidak menyibukkan diri dengan ilmu yang abstrak dan yang gaib-gaib. Sebelum ia telah selesai pelajaran atau pengertiannya dalam ilmu yang jelas, kongkret dan ilmu yang pokok-pokok.

4) Terangkanlah bahwa niat belajar itu supaya dapat mendekatkan diri kepada Allah, bukan untuk bermegah-megahan dengan ilmu pengetahuan itu. ${ }^{54}$

5) Guru wajib memberikan nasehat kepada murid-muridnya agar menuntut ilmu yang bermanfaat tersebut (menurut beliau) ialah ilmu tersebut nantinya akan membawa kepada kebahagiaan hidup akhirat, yaitu ilmu agama. ${ }^{55}$

6) Menasehati para murid dan melarang mereka agar tidak memiliki akhlak yang tercela, yaitu melalui sindiran tanpa menjatuhkan harga diri mereka. Guru harus terlebih dahulu beristiqamah. Setelah itu, dia meminta murid untuk beristiqamah. Apabila hal itu tidak dilakukan, nasehat tidak akan bermanfaat. ${ }^{56}$

${ }^{50}$ Fathiyyah Hasan Sulaiman, Alam Pikiran Al Ghazali Mengenai Pendidikan dan Ilmu, (Bandung : CV. Diponegoro, 1986), hal. 53.

${ }_{51}$ Ramayulis, Filsafat Pendidikan ...., hal. 399.

${ }^{52}$ Ali Al Jumbulati, Perbandingan Pendidikan ...., hal. 137.

${ }^{53}$ Muzayyin Arifin, Filsafat Pendidikan ...., hal. 94.

${ }^{54}$ Hamdani Ihsan dan Fuad Ihsan, Filsafat Pendidikan ...., hal. 105.

${ }^{55}$ Ali Al Jumbulati, Perbandingan Pendidikan ...., hal. 140.

${ }^{56}$ Abu Madyan Al Qurtubi, Mukhtashar Ihya' Ulumiddin, (Depok : Keira Publishing, 2014), Cet. Ke-1, hal. 19. 


\section{Pendidikan Islam dalam Perspektif al-Ghazali}

\section{H. Zulkifli Agus}

7) Guru hendaknya mencukupkan ilmu bagi murid tersebut menurut kadar pemahamannya. Maka iatidak menyampaikan kepada murid sesuatu yang tidak terjangkau oleh akalnya. ${ }^{57}$

8) Guru hendaknya harus memperhatikan perbedaan-perbedaan individual yang ada pada anak (murid) tersebut. Pandangan Al Ghazali mengandung himbauan agar guru memahami benar tentang prinsip-prinsip tentang perbedaan individual dikalangan anak didik serta tahapan perkembangan akal pikirannya, sehingga dengan pemahaman itu guru bisa mengajarkan ilmu pengetahuan sesuai dengan kemampuan mereka, dan berusaha sejalan dengan dengan tingkat kemampuan berpikir anak didiknya. ${ }^{58}$

9) Guru hendaknya mampu mengamalkan ilmunya. Menurut kebiasaan bahwa seorang guru adalah sebagai panutan, dan para siswa mengikuti apa yang ditujukkan oleh gurunya. Perumpamaan seorang guru yang baik dan benar adalah seperti benih yang ditanam di tanah dan bayangan dari tiang, maka bagaimana tanah itu tumbuh tanpa benih, dan mana mungkin bayangan itu bengkok sedangkan tiangnya lurus. ${ }^{59}$

10) Mempelajari hidup psikologis murid-muridnya. Guru harus dapat memahami jiwa anak didiknya. Dengan pengetahuan tentang anak didik, ia dapat menjalin hubungan yang akrab antara dirinya dengan anak didiknya. Secara praktis, guru harus mendidik mereka berdasarkan ilmu jiwa. ${ }^{6}$

Dalam pendidikan Islam, pendidik memiliki arti dan peranan yang sangat penting. Hal ini disebabkan karena ia memilki tanggung jawab dan menentukan arah pendidikan. Itulah sebabnya Islam sangat menghargai dan menghormati orang-orang yang berilmu dan bertugas sebagai pendidik.

\section{Peserta Didik}

Menurut Al Ghazali, anak adalah amanah Allah dan harus dijaga dan dididik untuk mencapai semua keutamaan dalam hidup dan mendekatkan diri kepada Allah. Semua bayi yang dilahirkan ke dunia ini, bagaikan sebuah mutiara yang belum diukur dan belum berbentuk, tetapi amat bernilai tinggi. Maka kedua orang tuanyalah yang akan mengukir dan membentuknya menjadi mutiara yang berkualitas tinggi dan disenangi semua orang. Maka ketergantungan anak kepada pendidiknya termasuk

kepada kedua orang tuanya, hendaknya dikurangi secara bertahap. ${ }^{61}$

Menurut Al Ghazali terdapat beberapa sifat penting yang harus dimiliki oleh

seorang murid, yaitu:

- Rendah hati

- Mensucikan diri dari segala keburukan

- Taat dan istiqamah. ${ }^{62}$

Al Ghazali menguraikan tentang tata kesopanan dan tugas-tugas seorang murid, yaitu antara lain:

1) Hendaknya murid bersih jiwanya dan menjauhi akhlak yang rendah serta sifat-Sifat tercela. Beliau mengatakan: "Wajiblah seorang murid bersih jiwanya dari akhlak yang rendah dan sifat-sifat yang tercela, karena kesucian jiwa dan kebaikan akhlak merupakan dasar bagi kecemerlangan dalam ilmu itu."63

\footnotetext{
${ }^{57}$ Al Ghazali, Ihya' Ulumiddin, (Semarang : CV. Asy Syifa, 2003), Jilid 1, hal. 177.

${ }^{58}$ Ali Al Jumbulati, Perbandingan Pendidikan ...., hal. 142.

${ }^{59}$ Abuddin Nata, Perspektif Tentang ...., hal. 101.

${ }^{60}$ Muzayyin Arifin, Filsafat Pendidikan ...., hal. 95.

${ }^{61}$ Hamdani Ihsan dan Fuad Ihsan, Filsafat Pendidikan ...., hal. 120.

${ }^{62}$ Ramayulis, Filsafat Pendidikan ...., hal. 399

${ }^{63}$ Ali Al Jumbulati, Perbandingan Pendidikan ...., hal. 166.
} 
Volume 3 Nomor 2 Edisi Desember 2018

P-ISSN : 2541-3686

2) Menyedikitkan hubungan-hubungannya dengan kesibukan dunia, dan menjauh dari keluarga serta tanah air. Karena hubungan-hubungan itu menyibukkan dan memalingkan. ${ }^{64}$

3) Tidak menyombongkan diri kepada ilmu. Seorang murid tidak boleh mengatur guru. Bahkan, dia harus menyerahkan segala keputusan kepada sang guru. Dia juga harus terus menerus berkhidmat kepada gurunya. ${ }^{65}$

4) Bagi pelajar permulaan janganlah melibatkan atau mendalami perbedaan pendapat para ulama, karena yang demikian itu dapat menimbulkan prasangka buruk, keragu-raguan dan kurang percaya pada kemampuan guru. ${ }^{66}$

5) Orang yang mencari ilmu tidak meninggalkan satu cabang ilmu yang terpuji, kecuali apabila jika seorang murid menyelam ke dalam ilmu tersebut hingga mendapatkan apa yang ia cari. Apabila usianya mendukungnya untuk melakukan pencarian itu, dia dapat menyempurnakan ilmu tersebut. Tetapi, apabila tidak, maka dia dapat memilih hal yang paling penting. ${ }^{67}$

6) Janganlah murid mendalami suatu ilmu atau teknik (seni) sebelum ia dapat memahami benar ilmu atau teknik (seni) yang telah dipelajari sebelumnya. Karena semua ilmu itu tersusun secara bertingkat-tingkat menurut keharusannya. Sebagian ilmu menjadi jalan bagi ilmu yang lainnya. ${ }^{68}$

7) Seorang pelajar agar dalam mencari ilmu selalu didasarkan pada upaya untuk menghiasi batin dan mempercantiknya dengan berbagai keutamaan. Hal ini didasarkan pada tujuan belajar yaitu untuk memperoleh kehidupan yang baik di akhirat. Hal itu tentunya tidak akan tercapai kecuali dengan membersihkan jiwa, menghiasi diri dengan keutamaan dan akhlak yang terpuji. ${ }^{69}$

8) Seorang pelajar harus mengetahui hubungan macam-macam ilmu dan tujuannya. Oleh sebab itu setiap pelajar harus menemukan maksud dan tujuan ilmu, dan yang paling penting adalah memilih ilmu yang dapat menyampaikan pada maksud tersebut. ${ }^{70}$

Anak adalah makhluk yang masih membawa kemungkinan untuk berkembang, baik jasmani maupun rohani. Ia memiliki jasmani yang belum mencapai taraf kematangan, baik bentuk, kekuatan maupun perimbangan bagian-bagiannya. Dalam segi rohaniah, anak mempunyai bakat-bakat yang harus dikembangkan. Ia juga mempunyai kehendak, perasaan dan pikiran yang belum matang. Di samping itu, ia mempunyai berbagai kebutuhan seperti kebutuhan pemeliharaan jasmani: makan, minum dan pakaian; kebutuhan akan kesempatan berkembang, bermain-main, berolahraga dan sebagainya. Selain itu, anak juga mempunyai kebutuhan rohaniah, Seperti kebutuhan akan ilmu pengetahuan duniawi dan keagamaan, kebutuhan akan

pengertian nilai-nilai kemasyarakatan, kesusilaan; kasih sayang dan lain-lain. ${ }^{71}$

Berdasarkan uraian- uraian di atas, maka kita dapat menyimpulkan bahwa Pendidikan Islam yang ada harus dapat dan mampu untuk membimbing, menuntun, mengembangkan, serta memenuhi kebutuhan-kebutuhan anak didik dalam berbagai bidang tersebut.

\section{Evaluasi Pendidikan Islam}

${ }^{64}$ Al Ghazali, Ihya' Ulumiddin ...., hal. 153.

${ }^{65}$ Abu Madyan Al Qurtubi, Mukhtashar Ihya' Ulumiddin, (Depok : Keira Publishing, 2014), Cet. Ke-1, hal. 15.

${ }^{66}$ Abuddin Nata, Perspektif Tentang ...., hal. 106.

${ }^{67}$ Abu Madyan Al Qurtubi, Mukhtashar Ihya' ...., hal. 16.

${ }^{68}$ Ali Al Jumbulati, Perbandingan Pendidikan ...., hal. 172.

${ }^{69}$ Abuddin Nata, Perspektif Tentang ...., hal. 107.

${ }^{70}$ Ibid., hal. 108.

${ }^{71}$ Muzayyin Arifin, Filsafat Pendidikan ...., hal. 119. 


\section{Pendidikan Islam dalam Perspektif al-Ghazali}

\section{H. Zulkifli Agus}

Proses pendidikan tidak terlepas pula dari beberapa komponen yang mendukungnya. Salah satu dari komponen yang urgen dalam melihat keberhasilan sebuah pendidikan yaitu penilaian. Konsep penilaian dalam diskursus pendidikan memiliki makna ganda, yaitu:

Pertama, penilaian ditempatkan sebagai salah satu aktivitas epistimologi pendidikan Islam yang berguna untuk "mengetahui" seberapa banyak hasil yang diperoleh dalam proses pendidikan.

Kedua, penilaian ditempatkan sebagai aksiologi pendidikan Islam yang berguna untuk "memberi muatan nilai" dalam setiap komponen dan proses pendidikan. ${ }^{72}$

Dalam dunia pendidikan, evaluasi memiliki manfaat, yaitu:

1) Manfaat bagi siswa

Dengan diadakannya evaluasi, maka siswa dapat mengetahui sejauh mana telah berhasil mengikuti pelajaran yang diberikan oleh guru. ${ }^{73}$

2) Manfaat bagi guru

Guru dapat mengetahui siswa-siswa mana yang sudah berhak melanjutkan pelajarannya karena telah berhasil menguasai bahan, dan mengetahui siswa-siswa yang belum berhasil menguasai bahan.

Guru akan mengetahui apakah materi yang diajarkan sudah tepat bagi siswa sehingga tidak perlu mengadakan perubahan untuk memberikan pengajaran di waktu yang akan datang. Guru akan mengetahui apakah metode yang digunakan sudah tepat atau belum. $^{74}$

Evaluasi dalam pendidikan Islam merupakan cara-cara atau teknik penilaian terhadap tingkah laku peserta didik berdasarkan standar perhitungan yang bersifat komprehensif dari seluruh aspek-spek kehidupan mental psikologi dan spiritual-religius, karena manusia hasil pendidikan Islam bukan saja sosok pribadi yang tidak beramal dan berbakti kepada Tuhan dan masyarakatnya. ${ }^{75}$

Kata evaluasi berasal dari bahasa Arab yaitu kata Muhasabah, yang berasal dari kata Hasiba yang berarti menghitung, atau kata Hasaba yang berarti memperkirakan. ${ }^{76} \mathrm{Al}$ Ghazali menggunakan kata tersebut dalam menjelaskan tentang evaluasi diri (Muhasabah an-Nafs) setelah melakukan aktifitas.

Penggunaan istilah ini, Al Ghazali mendasarkannya pada surat Al Hasyr ayat 18 sebagai landasan pokok dalam tindakan evaluasi diri:

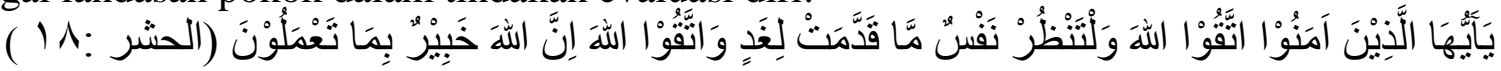
Artinya:

"Wahai orang-orang yang beriman! Bertaqwalah kepada Allah dan hendaklah setiap orang memerhatikan apa yang telah diperbuatnya untuk hari esok (akhirat), dan bertaqwalah kepada Allah. Sungguh, Allah maha teliti terhadap apa yang kamu kerjakan."

Evaluasi pendidikan Al Ghazali ini pada prinsipnya diarahkan sepenuhnya untuk mengetahui kondisi murid berkaitan dengan penilikan sejauh mana muridtelah dapat meresap ilmu pengetahuan yang didapat dalam pembelajaran danperkembangan kepribadian murid. Evaluasi pendidikan Al Ghazali berangkat dari teori dasar pendidikannya, yaitu al-Fadhilah.

${ }^{72}$ Ramayulis, Filsafat Pendidikan ...., hal. 439.

${ }^{73}$ Hamdani Ihsan dan Fuad Ihsan, Filsafat Pendidikan ...., hal. 215.

${ }^{74}$ Ibid., hal. 216.

${ }^{75}$ Hamdani Ihsan dan Fuad Ihsan, Filsafat Pendidikan ...., hal. 224.

${ }^{76}$ Atabik Ali dan Ahmad Zuhdi Muhdhar, Kamus Al Ashr, (Yogyakarta : Multi Karya Grafika, 1998), Cet . ke-9, hal. 764.

${ }^{77}$ Depag. RI Al Qurán dan Terjemahnya (Jakarta : Yayasan Penyelenggara Penerjemah al-Quran), hal. 919. 
Volume 3 Nomor 2 Edisi Desember 2018

P-ISSN : 2541-3686

Sebuah teori dasar yang melihatmurid sebagai sosok yang memiliki kecerdasan dan keutamaan lebih, sehingga evaluasi pendidikannya diarahkan untuk mengetahui:

a. Sikap dan pengamalan terhadap arti hubungan pribadinya dengan Tuhannya.

b. Sikap dan pengamalan terhadap arti hubungan dirinya dengan masyarakat.

c. Sikap dan pengamalan terhadap arti hubungan kehidupannya dengan alam sekitarnya.

d. Sikap dan pandangannya terhadap diri selaku hamba Allah dan selaku anggota masyarakat serta selaku khalifah di muka bumi (sebagai pemukiman lingkungan hidupnya). ${ }^{78}$

Keempat kemampuan dasar tersebut dijabarkan dalam klasifikasi kemampuan

teknik sebagai berikut:

a. Sejauh mana loyalitas dan kesungguhan untuk mengabdikan dirinya kepada tuhan dengan indikasi-indikasi lahiriah berupa tingkah laku yang mencermin-kan keimanan dan ketakwaannya kepada Tuhan.

b. Sejauh mana dan bagaimana seseorang selaku manusia hasil pendidikan Islam mampu menerapkan nilai-nilai agamanya dan kegiatan hidup bermasyarakat.

c. Bagaimana ia berusaha memelihara serta menyesuaikan dirinya dengan alam sekitar, apakah ia merusak lingkungan hidup, apakah ia mampu mengubah lingkungan sekitar menjadi bermakna bagi kehidupan diri dan masyarakat.

d. Bagaimana dan sejauh mana ia sebagai seorang muslim memandang dirinya sendiri dalam berperan sebagai hamba Allah yang harus hidup menghadapi kenyataan di dalam masyarakat yang beraneka macam budaya, suku, serta agama. ${ }^{79}$

Menurut Imam Al Ghazali, evaluasi pendidikan berarti usaha memikirkan, membandingkan, memprediksi (memperkirakannya), menimbang, mengukur dan menghitung segala aktifitas yang telah berlangsung dalam proses pendidikan, untuk meningkatkan usaha dan kreativitasnya sehingga dapat seefektif dan seefisien mungkin dalam mencapai tujuan yang lebih baik di waktu yang akan datang.

Adapun subjek evaluasi pendidikan adalah orang yang terkait dalam proses kependidikan meliputi: pimpinan, subjek didik, wali murid dan seluruh tenaga administrasi. Dan yang menjadi evaluasi pendidikan adalah semua bentuk aktifitas yang terkait dengan tugas dan tanggung jawabnya masing-masing dalam proses pendidikan. ${ }^{80}$

Teknik evaluasi pendidikan digunakan dalam rangka penilaian dalam proses belajar, maupun dalam kepentingan perbaikan situasi, proses serta kegiatan belajar mengajar. Adapun teknik penilaian itu ada dua, yaitu:

Pertama, Teknik tes: yaitu penilaian yang menggunakan tes yang telah ditentukan terlebih dahulu. Metode ini bertujuan untuk mengukur dan memberikan suatu penilaian terhadap hasil belajar yang dicapai oleh murid. Meliputi: kesanggupan mental, penguasaan akan hasil belajarnya, keterampilan, koordinasi, motorik, dan bakat.

Kedua, Teknik non tes: yaitu penilaian yang tidak menggunakan soal-soal tes. Yaitu dalam bentuk laporan dari pribadi mereka sendiri (self report). Hal ini bertujuan untuk mengetahui sikap dan sifat kepribadian murid yang berhubungan dengan kiat belajar atau pendidikan. Objek penilaian non tes ini meliputi: perbuatan, ucapan, kegiatan, pengalaman, keadaan tingkah laku, dan riwayat hidup. ${ }^{81}$

Dari uraian di atas, dalam pendidikan perlu adanya evaluasi. Tujuannya adalah agar dapat mengetahui sejauh mana tujuan pendidikan yang telah tercapai, dan untuk dapat

\footnotetext{
${ }^{78}$ Nur Uhbiyati, Ilmu Pendidikan Islam, (Bandung : CV Pustaka Setia, 1997), Cet. Ke-2, hal. 144.

${ }^{79}$ Hamdani Ihsan dan Fuad Ihsan, Filsafat Pendidikan ...., hal. 225.

${ }^{80}$ Abidin Ibnu Rusn, Pemikiran Al Ghazali Tentang Pendidikan, (Yogyakarta : Pustaka Pelajar, 1998), hal. 105

${ }^{81}$ Abuddin Nata, Filsafat PendidikanIslam, (Jakarta : Gaya Media Pratama, 2005), hal. 183.
} 


\section{Pendidikan Islam dalam Perspektif al-Ghazali}

\section{H. Zulkifli Agus}

mengetahui hambatan-hambatan apa saja yang menjadi penghambat tercapainya tujuan pendidikan tersebut.

\section{Simpulan}

Dari uraian di atas dapat disimpulkan bahwa pendidikan menurut Al Ghazali menekankan pada pendidikan agama dan akhlak. Menurutnya pengertian dan tujuan pendidikan Islam yaitu pendidikan yang berupaya dan bertujuan dalam proses pembentukan insan paripurna. Adapun dalam membuat sebuah kurikulum, Al Ghazali memiliki dua kecenderungan, yaitu kecenderungan terhadap agama dan kecenderungan pragmatis. Adapun aspek-aspek materi pendidikan Islam menurut pemikiran Al Ghazali adalah meliputi: pendidikan keimanan, akhlak, akal, sosial dan jasmani. Menurutnya guru yang baik itu selain cerdas dan sempurna akalnya, juga harus memiliki sifat-sifat yang terpuji. Adapun sifat yang harus dimiliki oleh seorang murid yaitu rendah hati, mensucikan diri dari segala keburukan taat dan istiqamah. Sementara yang menjadi evaluasi pendidikan adalah semua bentuk aktifitas yang terkait dengan tugas tanggung jawabnya masing-masing dalam proses pendidikan.

Konsep pendidikan Islam dalam pemikiran Al Ghazali ini sejalan dengan tujuan pendidikan di Indonesia saat ini. Dimana pendidikan nasional bertujuan untuk mencerdaskan bangsa dan mengembangkan manusia Indonesia seutuhnya, yaitu manusia yang beriman dan bertaqwa kepada kepada Tuhan Yang Maha Esa dan berbudi pekerti luhur, memiliki pengetahuan dan keterampilan, kesehatan jasmani dan rohani, kepribadian yang mantap dan mandiri serta rasa tanggung jawab. 
RAUDHAH Proud To Be Professionals qurnal Tarbiyakndamiyah

Volume 3 Nomor 2 Edisi Desember 2018

P-ISSN : 2541-3686

\section{DAFTAR PUSTAKA}

Al Qur'anul Karim

Al Jumbulati, Ali. 1994. Perbandingan Pendidikan Islam. Jakarta: PT Rineka Cipta.

Al Qurtubi, Abu Madyan. 2014. Mukhtashar Ihya' Ulumiddin. Depok: Keira Publishing.

An Nawawi. 2014. Riyadhus Shalihin dan Penjelasannya. Jakarta: Ummul Qura.

Arifin, Muzayyin. 2010. Filsafat Pendidikan Islam. Jakarta: PT Bumi Aksara.

As, Asmaran. 2002. Pengantar Studi Akhlak. Jakarta: PT Raja Grafindo Persada.

Ghazali, Bahri. 2001. Konsep Ilmu Menurut Al-Ghazali. Jakarta: Pedoman Ilmu Jaya.

Hawi, Akmal. 2006. Dasar-Dasar Pendidikan Islam. Palembang: IAIN Raden Fatah Press.

Ihsan, Hamdani, danIhsan, Fuad. 2007. Filsafat Pendidikan Islam. Bandung: CV Pustaka Setia.

Nata, Abuddin. 2000. Pemikiran Para Tokoh Pendidikan Islam. Jakarta: PT RajaGrafindo Persada.

Nata, Abuddin, 2001, Perspektif Islam Tentang Pola Hubungan Guru-Murid; Studi Pemikiran Tasawuf Al-Ghazali. Jakarta: PT Raja Grafindo Persada.

Nata, Abuddin, . 2009. Metodologi Studi Islam. Jakarta: PT Raja Grafindo Persada.

Primarni, Amie, dan Khairunnas. 2016. Pendidikan Holistik; Format Baru Pendidikan Islam Membentuk Karakter Paripurna. Jakarta: AMP Press, PT Al Mawardi Prima.

Ramayulis. 2015. Filsafat Pendidikan Islam. Jakarta: Kalam Mulia.

Sulaiman, Fathiyyah Hasan. 1986. Pikiran Al Ghazali Mengenai Pendidikan dan Ilmu. Bandung: CV Diponegoro. 
Pendidikan Islam dalam Perspektif al-Ghazali

H. Zulkifli Agus 